\title{
The role of toll-like receptor 4 in tumor microenvironment
}

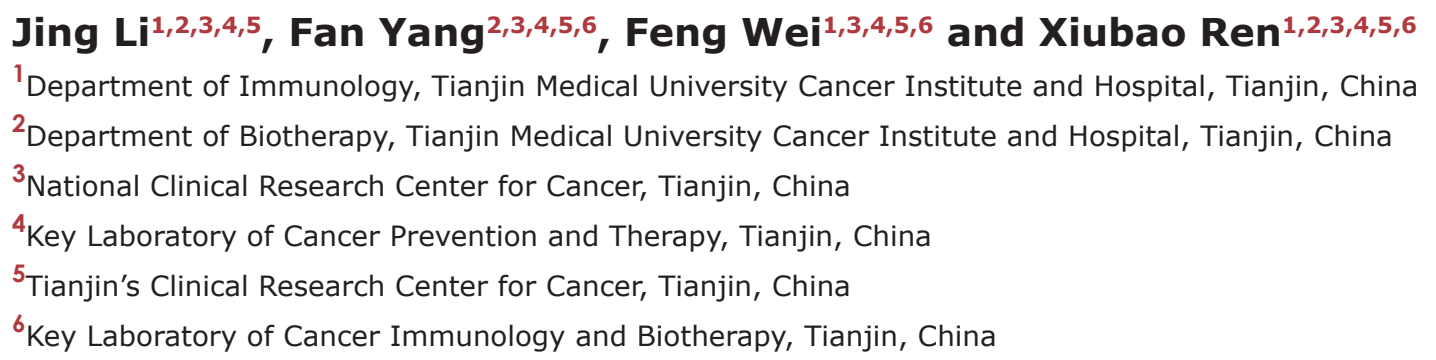

Correspondence to: Xiubao Ren, email: xiubaoren@163.com, rwziyi@yahoo.com

Keywords: TLR4, immune cells, tumor cells, tumor microenvironment

Received: November 24, 2016

Accepted: June 27, 2017

Published: July 08, 2017

Copyright: Li et al. This is an open-access article distributed under the terms of the Creative Commons Attribution License 3.0 (CC BY 3.0 ), which permits unrestricted use, distribution, and reproduction in any medium, provided the original author and source are credited.

\section{ABSTRACT}

Tumors are closely related to chronic inflammation, during which there are various changes in inflammatory sites, such as immune cells infiltration, proinflammation cytokines production, and interaction between immune cells and tissue cells. Besides, substances, released from both tissue cells attacked by exogenous etiologies, also act on local cells. These changes induce a dynamic and complex microenvironment favorable for tumor growth, invasion, and metastasis. The toll-like receptor 4 (TLR4) is the first identified member of the toll-like receptor family that can recognize pathogen-associated molecular patterns (PAMPs) and damage-associated molecular pattern (DAMPs). TLR4 expresses not only on immune cells but also on tumor cells. Accumulating evidences demonstrated that the activation of TLR4 in tumor microenvironment can not only boost the anti-tumor immunity but also give rise to immune surveillance and tumor progression. This review will summarize the expression and function of TLR4 on dendritic cells (DCs), tumor-associated macrophages (TAMs), T cells, myeloid-derived suppressor cells (MDSCs), tumor cells as well as stromal cells in tumor microenvironment. Validation of the multiple role of TLR4 in tumors could primarily pave the road for the development of anti-tumor immunotherapy.

\section{INTRODUCTION}

TLR is a type I transmembrance protein, which contains an extracellular domain and intracellular domain. At present, 11 mammalian TLRs have been identified. TLR4 is one of the most studied TLRs [1]. TLR4 was identified in Drosophila as a factor related to dorsoventral body patterning, and latter found in human body by Janeway and Medzhytov in 1997 [1]. Once being activated, TLR4 mainly initiates two different downstream pathways: MyD88-dependent and MyD88-independent signaling pathway. MyD88 activates transcription factors, containing nuclear factor-kappa $\mathrm{B}(\mathrm{NF}-\mathrm{kB})$ and activator protein-1 (AP-1), through IкB kinase (IKK) and mitogen-activated protein kinase (MAPK) pathway, which are favorable for transcription of inflammation factors. The other way is mediated by Toll/IL-1R domaincontaining adapter-inducing interferon- $\beta$ (TRIF) and toll receptor-associated molecule (TRAM) [2], which lead to expression of IFN- $\alpha$ and IFN- $\beta$, playing a role in resistance to virus. The TLR4 signaling pathway can be stimulated by varies ligands of TLR4 such as PAMPs and DAMPs in vivo $[3,4]$. Among which, DAMPs rather than PAMPs play a main role in activating TLR4 in tumor microenvironment. TLR4 and MyD88 have been demonstrated over expression in breast cancer [5], suggesting the possible role of TLR4 signaling pathway in tumor microenvironment. TLR4 is expressed not only on tumor cells but also on stromal cells and immune cells that play vital role in antitumor in tumor microenvironment. Many TLR4 ligands have been identified in tumor tissue in recent years. Nevertheless, a growing body of evidences have pointed out the existing of immune inhibitory cells, such as TAMs, and MDSCs, which are considered as the major factors for the suppression of immune response in tumor microenvironment. Of note, macrophages 
in tumor microenvironment were found to show protumor or anti-tumor functions in various studies [6-9]. Accumulating evidences demonstrated that the activation of TLR4 in tumor microenvironment can boost the antitumor immunity [10-12] including dendritic cells (DCs) maturation, and antigen presentation. However, TLR4 activation on tumor or on stromal cells promotes immune surveillance and tumor progression [13]. NF- $\kappa \mathrm{B}$ is active in macrophages during the stimulation of inflammatory cytokines and partly contributes to tumor progression. A positive correlation between abundant TAMs and poor prognosis has been demonstrated by a great amount of clinical studies concerning prostate cancer [14], gliomas [15] and non-small lung carcinoma [16]. In Yusuf's study, TLR4 deficient mice are more susceptible to cutaneous 7,12-dimethylbenz induced carcinogenesis, indicating a role of TLR4 in preventing tumorigenesis [17]. In another relevant study, effective chemopreventive agent was used before 7,12-dimethylbenz, and IFN- $\gamma$ and IL-12 levels were increased in TLR4 competent mice compared to TLR4 deficient mice, suggesting that TLR4 is an important mediator of chemoprevention in 7,12-dimethylbenz skin tumorigenesis [18]. Furthermore, activation of TLR4 on DC by adjuvants including BCG cell-wall skeleton (BCG-CWS), M. tuberculosis protein Rv0652 [19], Heat shock protein X (HspX), Hyaluronan [20], and Angelan $[21,22]$, leads to enhanced maturation and migration of DCs, macrophage activation, naïve $\mathrm{T}$ cell proliferation as well as Th1 immune response, which all play a positive role in antitumor immune therapy. Additionally, TLR4 signaling has also been shown to partially reconstruct destroyed vasculature at the site of damage by recruiting the provascular progenitors from bone marrow (BM) and spleen to inflamed tissue [23]. high-mobility group box1 protein(HMGB1), ligand of TLR4 has been reported correlation to integrin-dependent homing of endothelial progenitor cells [24]. Interestingly, the similar effect of TLR4 on angiogenesis is also discovered in tumor microenvironment. Therefore, this review focused on the expression and function of TLR4 on DCs, TAMs, $\mathrm{T}$ cells, MDSCs, tumor cells and stromal cells in tumor microenvironment.

\section{The effect of TLR4 on DCs activation and maturation}

DCs act as the most powerful antigen presenting cells (APCs) and critical mediators of adaptive immune responses. The two main populations of DCs recognized in mouse and human tissues are myeloid DCs (mDCs) and plasmacytoid DCs (pDCs). Among them, the expression of TLR4 is restricted to mDCs. Following LPS stimulation, DCs separated from pigs presented an enhanced TLR4/ MyD88-dependent gene expression, CD40 and CD86 on the cell surface, as well as chemokine and proinflammatory cytokine expressions [25] (Figure 1). Mature
DCs are able to induce T helper 1 (TH1) -type immune responses, and are also viewed as potent initiators of tumor associated antigen (TAA)-specific immunity. Interestingly, Davis et al. [26] found that intratumoral treatment of LPS, acting as TLR4 agonist, combined with granulocytemacrophage colony-stimulating factor (GM-CSF) gene modified tumor vaccine (GVAX), enhanced maturation of APC in tumor microenvironment and induced efficient anti-tumor response. Small difference was found in mice with ${\mathrm{MyD} 88^{-/-} \text {as well as MyD88 }}^{-/-} \mathrm{TRIF}^{-/-}$genotypes between GVAX and PBS treated group, suggesting this process was in a TLR4-dependent pathway. Additionally, an ocean of adjuvants, such as pancreatic adenocarcinoma up-regulated factor (PAUF) [27], Polysaccharides [28], high-mobility group nucleosome-binding protein 1 (HMGN1) [29], angelan [22], can induce activation and maturation of DCs through TLR4 (Figure 1).

However, growing evidences demonstrated that functional mature DCs are rare in human cancers. This may result from various factors, such as lack of DC recruitment, differentiation, activation, maturation, or survival. It was note that both differentiation and maturation of mDCs can be suppressed by imbalance of cytokines in the tumor microenvironment. Furthermore, Zhong et al. [30]also found that $\mathrm{mDCs}$ can be polarized into functional regulatory DCs (regDCs) in the lung cancer microenvironment in vitro and in vivo. There was also a suppressed proliferation of pre-activated $\mathrm{T}$ cells with the development of regDC, which were confirmed with a potential pro-tumorigenic activity in tumorbearing mice [30]. Furthermore, the progression of lung cancer is relevant to fast and significant accumulation of immunosuppressive regDC in both lymphoid tissues and tumor microenvironment [30]. The transformation from conventional DC (conDC) to regDC has been blocked by the use of noncytotoxic doses of paclitaxel through the small Rho GTPase signaling in a TLR4 independent way [30]. In consideration its crucial role in DC activation [31], maturation [32], differentiation [32, 33] as well as migration [34], TLR4 may be a underlying member in transformation between conDCand regDC, though there was no evidence on relationship of regDC and TLR4 at present.

\section{TLR4-induced inflammation in tumor leads to the infiltration of $\mathrm{M} 2$ macrophages}

Macrophages in tumor microenvironment are often divided into two classically activated macrophages (or M1) and alternatively activated macrophages (or M2). The M1 phenotype is polarized by Th1 cytokines such as IFN- $\gamma$ and characterized by high capacity, high levels of inflammatory cytokines secretion, so it enhanced ability to kill intracellular pathogens and tumor cells. In contrast, M2 macrophages are induced by Th2 cytokines such as IL-4 and IL-13, and marked by decreased production of 
IL-12 and increased production of IL-10 [35]. TAMs, important constituents of tumor microenvironment, have been regarded as M2 phenotype, playing a key role in promoting tumorigenesis and progression. For decades, accumulating evidences has revealed a positive correlation between advanced number and/or density of macrophage in tumors and poor prognosis of sufferers $[35,36]$.

Lee et al. [37] have found a potential role for TLR4 signaling in inflammation and regulating the permeability of the lung tissue by comparing the levels of proteins in the bronchoalveolar lavage (BAL) fluid. Simultaneously, a 1.69-fold amplification of the number of macrophages exists in the BAL fluid stemmed from wild-type mice bearing melanoma when compared with that from tumorbearing TLR4-deficient mice, the result suggested that TLR4 may play a role in macrophage migration [37]. Studies have also shown that activation of $N F-\kappa B$ in TAMs is essential for the production of pro-inflammatory cytokines and angiogenetic factors, such as metal matrix proteinase 9 (MMP-9), TNF- $\alpha$, and vascular endothelial growth factor (VEGF) [37-39] (Figure 2).

In a recently study, a larger number of TAMs has been observed in mice exposed with sleep fragmentation (a hallmark of sleep apnea and associated with increased tumor incidence and mortality) compared with that in mice exposed with sufficient sleep [40], at the same time, TAMs secreted from the tumor of mice with sleep fragmentation had a higher level of TLR4 expression than that from the tumor of the latter, which indicates that TLR4 signaling in macrophages may play a role in recruiting macrophages from systemic circulation to the tumor microenvironment [40] (Figure 2). Significant reductions in TAMs count appeared in TLR4 $/$ mice, indicating the potential role of
TLR4 in macrophage recruitment [40]. A retrospective study on 81 patients diagnosed with diffuse large B-cell lymphoma (DLBCL) has shown a significant correlation between TAMs and TLR4 by immunohistochemistry experiment, this study implied that TLR4-induced inflammatory may be responsible for the TAMs collection in tumor microenvironment [41]. Above all, TLR4 expressed on TAMs is one component of mechanisms responsible for the recruitment of macrophages into tumor microenvironment.

\section{The relation between TLR4 and T cells in tumor microenvironment}

CD4+ T cells can be mainly differentiated into Th1, Th2, $\mathrm{T}$ helper 17 (Th17), regulatory $\mathrm{T}\left(\mathrm{T}_{\text {reg }}\right)$ as well as $\mathrm{T}$ follicular helper cells, all of which play a dynamic role in immune responses to not only infectious diseases but also cancer. The Th1 response can be enhanced by a variety of TLR4 agonists, such as glucopyranosyl lipid A-stable emulsion (GLA-SE) and LPS. Studies have found that synthetic GLA can definitely upregulate the CD4+ T cell response with increased production of IFN- $\gamma$ and TNF [42, 43]. Consistently, recently studies verified that adjuvant GLA-SE led to the existence of CD4+ CTLs, newly found members with the function of killing autologous B cells presenting MHC II complex [44], suggesting the momentous character of TLR4 in activating CD4+CTLs. This newly defined function of CD4+ $\mathrm{T}$ cells relies on CD40L engagement of CD40 in target cells rather than previously discovered certain CTL mechanism [44]. CD4 CTL expressed some markers related to cytotoxic functions of CD8 CTL, such as natural killer group 2

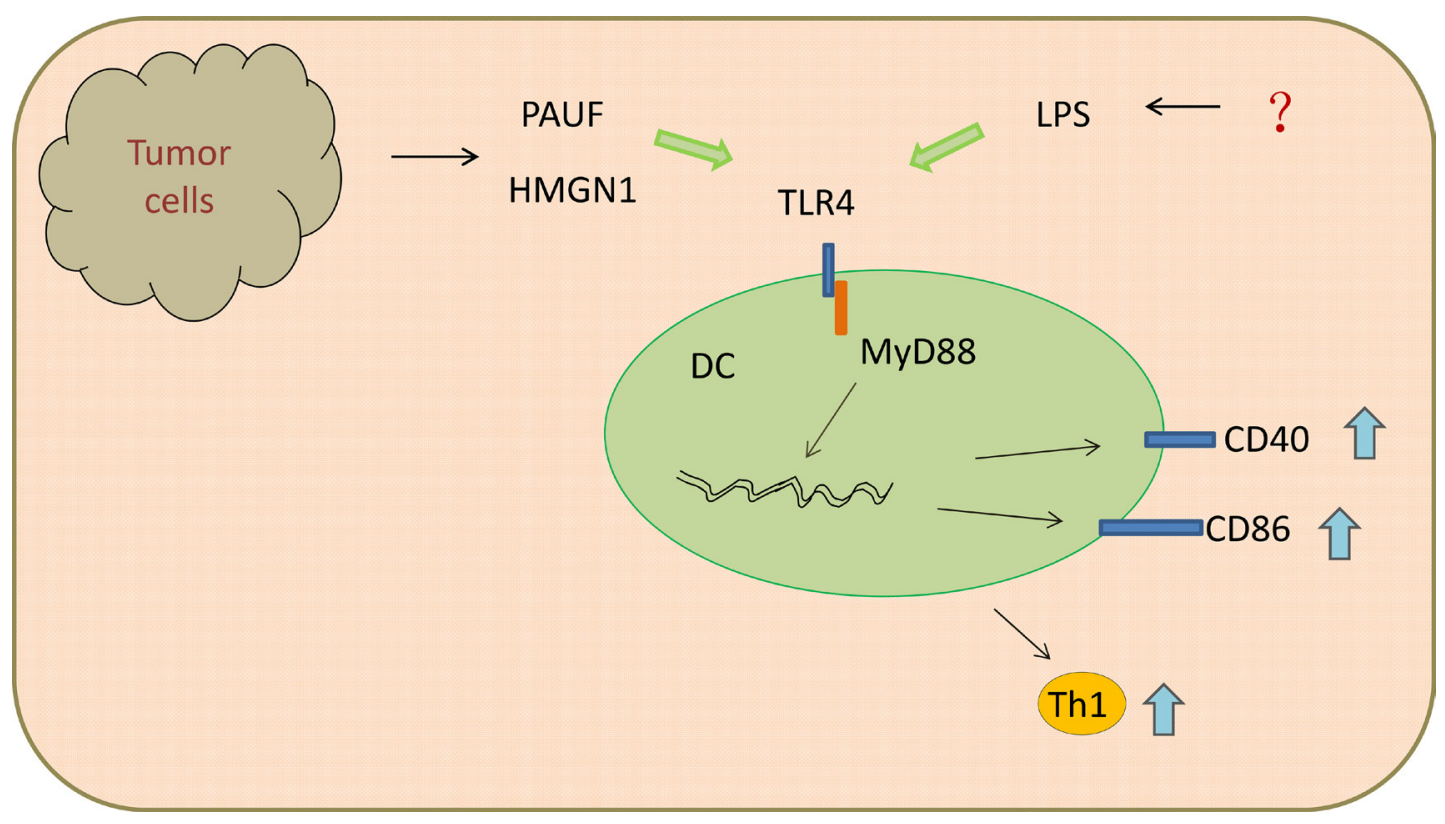

Figure 1: Ligands of TLR4 promoted DCs maturation and Th1 anti-tumor immunity through MyD88-dependent pathway. 
(NKG2A) and NKG2D [45, 46]. Considering the role of CD4 CTLs in controlling HIV, malaria, and other infections $[47,48]$, it is intriguing to speculate about the activity of CD4 CTLs in tumor environment after TLR4 agonist adjuvant. Nevertheless, a review has also revealed that CD4 CTL affect both protective and pathogenic immunity, so the function of CD4 CTL on tumor cells in tumor microenvironment should be ulteriorly researched by more studies [49].

Moreover, a study comparing the phenotype of human $\mathrm{CD}^{+}{ }^{+} \mathrm{CD} 25^{+} \mathrm{CD} 127^{-} \mathrm{T}_{\text {reg }}$ and $\mathrm{CD} 4^{+} \mathrm{CD} 25^{-} \mathrm{CD} 127^{-}$ conventional $\mathrm{T}$ cells $\left(\mathrm{T}_{\text {con }}\right)$ showed that levels of TLR4 expressed on $\mathrm{T}_{\text {reg }}$ and $\mathrm{T}_{\text {con }}$ are similar, different with that of the receptor for advanced glycation end products (RAGE), which is higher on $\mathrm{T}_{\text {reg }}$ than on $\mathrm{T}_{\text {con }}$ [50]. The HMGB1, ligand of both TLR4 and RAGE, has been found to dampen the proliferation of $\mathrm{CD}^{+} \mathrm{CD} 25^{-} \mathrm{T}_{\text {con }}$ through activating TLR4 [50]. On the other hand, HMGB1 dramatically enhanced the IL-10 secretion of $\mathrm{T}_{\text {reg }}$ [50]. Additionally, the enhanced release of IL10 was inhibited when anti-TLR4 antibody was added before or during HMGB1 stimulation [50], confirming that TLR4 is responsible for the elevated production of IL-10. IL-10 is a well known immunosuppressive cytokine in tumor microenvironment, and its increased levels are correlated with poorer prognosis of cancer patients [51, 52]. Furthermore, Liu et al. [53] has also revealed that the previous enhanced IL-10 production can further lead to the suppression of CD8+ T cell-dependent antitumor immunity in tumor microenvironment. Studies have shown that the number of tumor-infiltrating $\mathrm{T}$ cells was positive correlated with secretion of HMGB1 by cancer cells [54], specialists speculated that the underlying mechanism may be related to activation of TLR4 by HMGB1 in tumor microenvironment. In aggregate, activation of TLR4 on $\mathrm{T}$ cells by ligands in tumor microenvironment might have both anticancer and pro-tumor consequences through multiple mechanisms.

\section{TLR4 accounts for the accumulation and function of MDSCs in tumor microenvironment}

MDSCs, a heterogeneous population of immature myeloid cells, are known for its immune-suppressive function during chronic inflammation and tumor development. MDSCs are defined as $\mathrm{Gr}-1^{+} \mathrm{CD} 11 \mathrm{~b}^{+}$cells comprising pathologically activated $\mathrm{CD} 11 \mathrm{~b}^{+} \mathrm{Ly} 6 \mathrm{C}^{\mathrm{low}} \mathrm{Ly} 6 \mathrm{G}^{+}$ immature granulocytes and $\mathrm{CD}_{11 \mathrm{~b}^{+} \mathrm{Ly}_{6} \mathrm{C}^{\text {high }} \mathrm{Ly} 6 \mathrm{G}^{-}}$ monocytes $[55,56]$. MDSCs can be induced by proinflammatory cytokines such as IFN- $\gamma$, interleukins, GM-

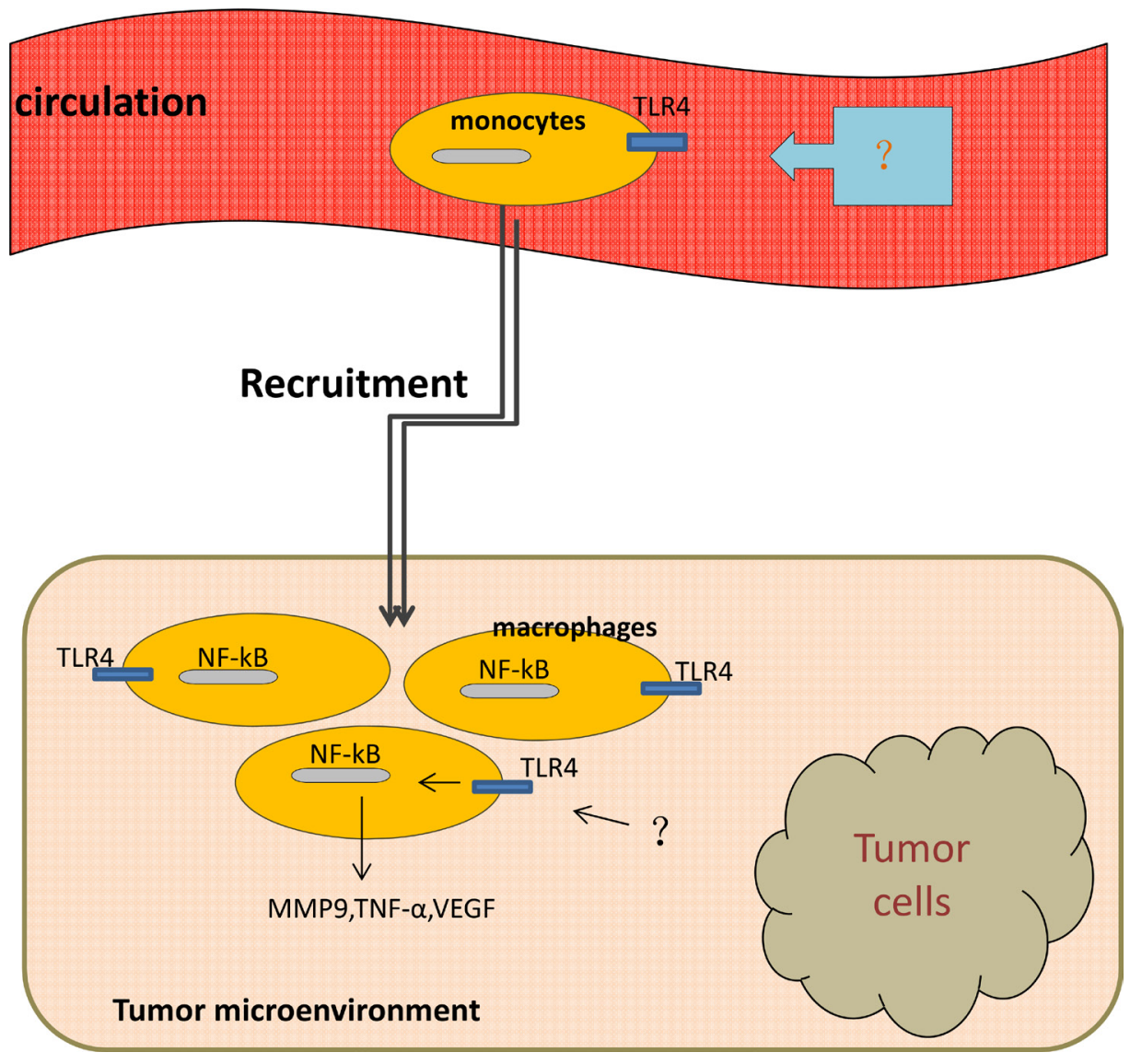

Figure 2: Macrophages move from circulation to tumor microenvironment with the activation of TLR4 on them. Once been activated, TLR4/NF- $\mathrm{B}$ signaling pathway induces production of MMP-9, TNF- $\alpha$, VEGF by tumor-associated macrophages. 
CSF, and TNF. However, the accumulation and function of MDSCs in the tumor microenvironment has not been well clarified. Chronic inflammation has been demonstrated to boost the aggregation of MDSCs. One recent study has testified that IL-17 promotes MDSCs recruitment in lung cancer induced by K-ras mutation [57] (Figure 3). Studies have also manifested that MDSCs played a role in inhibiting anti-tumor immunity by abrogating the activation of CD4+ and CD8 $+\mathrm{T}$ cells, the activity of macrophages and NK cells, and the maturation of DCs. Bunt et al. [58] reported that MDSCs can be activated by IL-1 $\beta$-induced inflammation through the TLR4 / CD14 protein pathway, which enhanced the interaction between MDSCs and macrophages (Figure 3). This is the first study that has reported the expression of TLR4 in MDSCs. In addition, the suppressive activity of MDSCs needs to be induced by activated T cells and tumor stroma cells, such as IFN- $\gamma$, TGF- $\beta$, IL-13, IL-4, and certain ligands for TLRs [59]. The elevated production of IL-10 by IL-1 $\beta$-induced MDSCs and down-regulated production of IL-12 converted tumor immunity from a tumor-rejecting type 1 response to a tumor-promoting type 2 response [59] (Figure 3), which promotes tumor growth. Srivastava et al. showed that a significant increase of MDSCs resulted from the injection of Lewis lung carcinoma (LLC) cells into C57BL/6 mice [60]. Of note, there is a inhibition of tumor volume, tumor weight as well as metastases and a reduction of Gr1-expressing cells in the tumor, blood, spleen and bone marrow after the application of anti-Gr1 or anti-Ly6G [60]. Moreover, the expression of TLR4 protein as well as the number of $\mathrm{CD}_{1} 1 \mathrm{~b}^{+} \mathrm{Gr} 1^{+}$ cells in lung tissue are higher in urethane-treated mice than that in lungs of control group [61], which indicates that TLR4 may involve in the accumulation of MDSCs. Meanwhile, monophosphoryl lipid A, derived from LPS and also defined as a TLR4 agonist, led to a significantly accumulation of MDSC in vitro and in vivo [62].

$\mathrm{Gr}-1^{+} \mathrm{CD} 11 \mathrm{~b}^{+} \mathrm{F} 4 / 80^{+}$cells have been defined as another type of MDSCs in tumor-bearing mice, and have also been found with the capacity of inducing apoptosis of activated T cells [63]. Naive Gr- $1^{+} \mathrm{CD} 11 \mathrm{~b}^{+} \mathrm{F} 4 / 80^{+}$bone marrow derived monocytes (BMDMs) in palpable tumor could not inhibit $\mathrm{T}$ cell activation without the stimulation of molecules from necrotic tumor cells (NTC-Ms) [64]. However, further study showed that interferon regulatory factor 3 (IRF-3), but not NF- $\mathrm{B}$, was activated in BMDMs in response to NTC-Ms, indicating that TRIF pathway was involved. The ability of BMDMs, stimulated by NTC-Ms, to induce apoptosis of activated $\mathrm{T}$ cells was suppressed by an inhibitor of TRIF pathway [65], suggesting that TLR4 ligands in NTC-Ms aroused the apoptosis-inducing capability of Gr-1+CD11b+F4/80+ BMDMs, which was

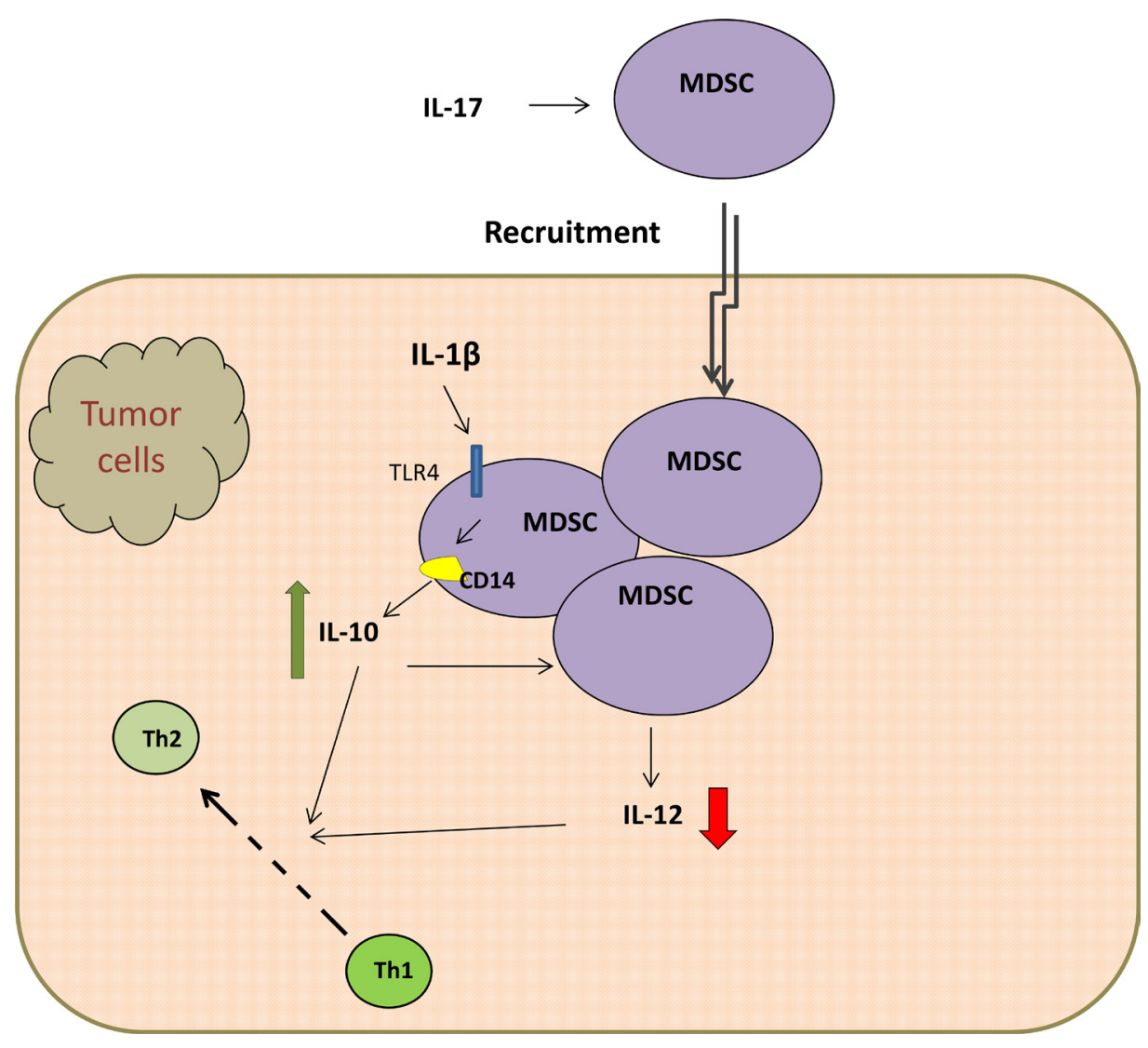

Figure 3: TLR4 / CD14 protein pathway elevated production of IL-10 by MDSCs and down-regulated IL-12 production, which both convert tumor immunity from a tumor-rejecting type 1 response to a tumor-promoting type 2 response. 
further confirmed by the use of sTLR4 expression vector in palpable tumor [64]. PAUF, a soluble protein involved in pancreatic tumorigenesis and metastasis, interacted with TLR4 on the surface of MDSCs and enhanced their immunosuppressive effects on activated T cells in tumor microenvironment [66]. Furthermore, wilde et al. have found that repetitive injections of LPS induced a cluster of MDSC-like cells, which mediate suppression of T cell response on vitro [67]. In one word, TLR4 may be in charge of MDSCs accumulation and enhance its capacity of inducing-apoptosis of T cells.

\section{TLR4 promotes angiogenesis in tumor microenvironment}

Angiogenesis, the formation of new blood vessels mediated by endothelial cells (ECs) and endothelial progenitor cells (EPCs), both of which can migrate to tumor cells, after that, proliferate and act as active factors in tumor microenvironment. Elevated TLR4 messenger RNA expression of blood vessels was found in antiphospholipid syndrome (APS) associated with increased rates of cardiovascular morbidity and mortality [68], suggesting a role of TLR4 in angiogenesis regulation. Lin et al. [69] firstly demonstrated that TLR4 may involve in angiogenesis induced by HMGB1. When combined with HMGB1, TLR4 expressed on neutrophils or macrophages activates IkB kinase (IKK) $-\beta$ and IKK- $\alpha$, and leads to the activation of $N F-\kappa B$, resulting in the release of VEGF [70], a crucial mediator in pathological angiogenesis. In addition, Zhu et al. [71]. compared the effect of all-thiol form (at-HMGB1) and disulfideHMGB1 (ds-HMGB1), two different redox states of HMGB1, on angiogenesis of colorectal carcinoma, and showed that at-HMGB1 stimulates ECs migration through interacting with RAGE, and ds-HMGB1 induced VEGF-A secretion by ECs through TLR4, both of which leaded to neovascularization in tumor microenvironment. Moreover, extracellular peroxiredoxin 1 (Prx 1) has also been defined as a TLR4 ligand [72]. Riddell et al. [73] found that the number of vessels and overall vascular areas are increased in prostate cancer $(\mathrm{CaP})$ cell line (PC-3M) shPrx1 tumors, which expressed Prx1 specific shRNA that can lead to a $50 \%$ reduction in Prx 1 expression, rather than in control group in which tumors expressing non-specific shRNA. Furthermore, analysis of angiogenetic protein expression in PC-3M tumor lysates showed that VEGF secretion is notably reduced in shPrx 1 cells as well as scramble cells, which both were transfected with vectors encoding a MyD88 domain negative(DN) cDNA, suggesting that TLR4-MyD88 pathway is involved in the production of VEGF mediated by Prx1 [73]. The role of TLR4 in the Prx1 induction of VEGF expression in prostate tumors has been further turned out to be dependent on the interaction of hypoxia inducible factor-1 (HIF-1) and VEGF enhancer $\mathrm{NF}-\kappa \mathrm{B}$ in tumor microenvironment [74].
Recently, in a study of the role of HMGB1-TLR4 signaling pathway in promoting EPCs recruitment in a mouse model following alkali, an increased level of EPCs recruitment was detected in injured corneas when recombinant HMGB1 and an exogenous TLR4 agonist-LPS were administered to the corneas after alkali-injured [23]. Meanwhile, this phenotype was reversed by inhibiting the activity of HMGB1 and LPS [23]. Moreover, the role of TLR4 in facilitating EPCs collection was related to over expression of a vital cytokine in EPCs mobilization, which was considered as stromal cell-derived factor 1 (SDF-1) [23]. Another study showed that biglycin (BGN), an important constituent of the extracellular matrix in variety tumors, promotes tube formation, migration and proliferation of ECs in a TLR2/4 signaling pathway [75]. Therefore, TLR4 takes an important part in facilitating the formation of vessels in tumor microenvironment through multiple mechanisms.

\section{MSCs expedite tumor development partially through TLR4 signaling pathway}

Mesenchymal stem cells (MSCs) are multifunctional cells derived from adipose tissue, bone marrow, and some other tissues. As a type of tumor stromal cell, MSCs promote tumor growth and metastasis by secreting cytokines and chemokines in tumor microenvironment [76, 77]. Shi et al. [78] have first found that bone marrowderived MSCs expressed TLR4 mRNA and functional TLR4. It has been ulteriorly demonstrated that TLR4 expression on MSCs have a positive effect on the Tcell response $[79,80]$ and $\mathrm{B}$ lymphocyte-related immune regulation [81]. Down-regulation of TLR4 signal pathways in bone marrow mesenchymal stem cells (BMSCs) gave rise to the reduction of IL- $1 \beta$ and TNF- $\alpha$ in bone tissue, thus contributed to efficient control of spinal cord inflammation [82]. Recently, Lu's study manifested that the levels of TLR4 mRNA expression in MSCs isolated from bone marrow of patients with acute myeloid leukemia (AML-MSC) as well as from the patients' lung cancer tissues (LC-MSC), were much higher than that in MSCs obtained from the bone marrow of healthy volunteers (BM-MSC) [83]. The secretion of IL-6 and IL-8 by the sorted TLR4-positive MSCs (TLR4+ MSCs) was lower than that by unsorted MSCs. Meanwhile, the levels of IL-6 and IL-8 was significantly upregulated by LPS and the amplified effect was larger in TLR4+ MSCs than that in unsorted MSCs [83]. However, the level of MSC-derived monocyte chemotactic protein-1 (MCP1), was much higher in the supernatant of TLR4+MSCs, suggesting that TLR4 may play a vital role in induction of MCP-1, which has been defined as a promoter in breast cancer cell migration [84]. The expression NKG2D receptor on NK cells as well as the multiplication capacity and cytotoxicity of NK cells were both inhibited after co-culturing with TLR4+MSCs [83]. Interestingly, the 
suppression of NK cell cytotoxicity was more remarkable following treatment with LPS and recovered by damping the TLR4 function [83], suggesting that TLR4 expression on MSC play a crucial role in inhibiting NK cell function in tumor microenvironment [83].

\section{TLR4 expressed on tumor cells}

It was verified that TLR4 also expresses in many type of tumors, such as hepatocarcinoma, glioblastoma, lung cancer and breast tumor [85-88]. TLR4 were found to be recognized by extracellular HSP70 in the tumor microenvironment, and it plays a positive role in proliferation and migration of tumor cells [89]. Recently, HSP70 induced an increased expression of nuclear NF- $\mathrm{KB}$ and an enhanced proliferation of $\mathrm{H} 22$ hepatocarcinoma cells, however, this function was later inhibited by resveratrol, a TLR4 signaling inhibitor [86]. In another study, EGFR transactivation, which may contribute to cell migration, induced by HSP90a in U87 glioblastoma cells was inhibited with the down-regulation of TLR4, indicating that HSP90a promotes glioblastoma cells migration through the interacting with TLR4 [85]. Furthermore, over expression of TLR4 on hepatocellular carcinoma cells was positively correlated with the number of $\mathrm{CD} 4+\mathrm{CD} 25^{\text {high }} \mathrm{FOXP} 3+\mathrm{T}_{\text {reg }}$ in tumor tissue, which leads to immune tolerance and tumor progression. Metadherin (MTDH) was definitely known as a protein associated with tumor progression and metastasis in cervical cancers $[90,91]$. The expression of MTDH are presented at a higher levels in TLR4 positive breast cancer cells (MDAMB-231,MCF-7, and MDA-MB-468) than that in TLR4 negative T47D cell lines after treated with LPS, suggesting the pro-tumor role of TLR4 expressed on tumor cells [92]. Furthermore, TLR4 has also been reported correlation with metastasis of breast cancer cells [93, 94] and has down favor on poor survival of breast cancer patients [95].

In addition to endogenous ligands secreted by necrotic tumor cells, TLR4 is also directly activated by paclitaxel, a chemotherapeutic drug against various human cancers. Paclitaxel brought out robust inflammatory responses and tumor growth in TLR4 positive cells, but not in TLR4 negative cells [10], indicating that TLR4 may be a underlying reason for the resistance to chemotherapy. Mallick et al. [96] have found that paclitaxel altered the expression of key enzymes involved in irinotecan metabolism in TLR4-dependent mechanism, which demonstrated that TLR4 could be a novel mediator of paclitaxel and irinotecan drug-drug interaction. Furthermore, dysregulation of gene TLR4 was associated with cisplatin resistance in human squamous cell carcinoma [97]. As previously shown, Prx1 interaction with TLR4 on CaP cells promoted prostate cancer growth through chronic activation of tumor angiogenesis [73, 74]. Consistently, knockdown of TLR4 via TLR4 siRNA in human breast cancer cell line MDA-MB-231 induced a decreased secretion of cytokines including IL-6 and IL8 , and a inhibition in proliferation and survival of these cells [98]. Meanwhile, TLR4 RNA expression in breast cancer with node metastasis is much higher than that without node metastasis [88]. These results suggested that of TLR4 on tumor cells may be a potential therapy for breast cancer.

Studies have also shown that the expression of TLR4 are higher in non-small cell lung cancers (NSCLC) than that in normal tissues and the expression of its serum soluble pattern may act as a biomarker to predict radiation pneumonia risk in local advanced NSCLC patients $[99,100]$. In addition, TLR4 expression is associated with tumor stage. One study of 37 patients with stage II and III colon cancer has shown that TLR4 expression was significantly higher in stage III tumors than stage II [101]. Previous study has also found a rising tendency on the NSCLC stage from I to III [102]. Furthermore, high expression of TLR4 in human hepatocellular carcinoma (HCC) tissues has also been found associated with poor survivals in patients [103]. On the contrary, our previous study has shown that low levels of serum soluble TLR4 were associated with poor survival of early stage NSCLC patients [104]. Meanwhile, serum TLR4 levels of patients with distant metastasis was much lower than that of patients without metastasis [104]. These results suggested that serum TLR4 maybe a biomarker of tumor metastasis and prognosis. Serum TLR4 is the soluble form of its extracellular domain on cells, there is a hypothesis that the extracellular domain of TLR4 may crack from tumor cells with the development and metastasis of tumor.

\section{CONCLUSIONS AND PROSPECT}

Although TLR4 activation on tumor cells, stroma cells as well as vascular epithelial cells definitely benefits the tumor, stimulation of this pathway in immune cells may have two reversal consequences. TLR4 expressed on DCs play a role in promoting anti-tumor immune response, but that expressed by MDSCs, vascular epithelial cells, macrophages MSCs and tumor cells play the opposite role. Furthermore, activation of TLR4 on $\mathrm{T}$ cells have anticancer and pro-tumor consequence in tumor microenvironment. Meanwhile, studies found that serum TLR4 maybe a biomarker of tumor metastasis and prognosis. Immunotherapy is the fourth and promise therapeutic method following surgical, chemotherapy and radiotherapy. The in vitro and in vivo experiments indicated that multiple substances functioned as immune adjuvant through binding to TLR4 on DCs, and played a promising role in anti-tumor therapy. Immunomax, a new defined TLR4 agonist, prolongs the survival of mice following primary 4T1 tumor resection by activating DCs and NK cells co-operation in tumor microenvironment [94]. In view of the "double-edged sword" role of TLR4 activation, from my own perspective, the potential role 
of TLR4 in tumor microenvironment needs to be further clarified.

\section{CONFLICTS OF INTEREST}

No conflicts of interest exists in the submission of this manuscript, and manuscript is approved by all authors for publication.

\section{FUNDING}

This work has been funded, in part, by grants from the National Natural Science Foundation of China (No. 81672697) and National Major Scientific and Technology Special Project for "significant New Drugs Development" (No.2015ZX09102018).

\section{REFERENCES}

1. Medzhitov R, Preston-Hurlburt P, Janeway CA Jr. A human homologue of the Drosophila Toll protein signals activation of adaptive immunity. Nature. 1997; 388:394-7. doi: $10.1038 / 41131$

2. Fitzgerald KA, Palsson-McDermott EM, Bowie AG, Jefferies CA, Mansell AS, Brady G, Brint E, Dunne A, Gray P, Harte MT, McMurray D, Smith DE, Sims JE, et al. Mal (MyD88-adapter-like) is required for Toll-like receptor-4 signal transduction. Nature. 2001; 413:78-83. doi: $10.1038 / 35092578$.

3. Janeway CA Jr, Medzhitov R. Innate immune recognition. Annu rev immunol. 2002; 20:197-216. doi: 10.1146/ annurev.immunol.20.083001.084359.

4. Akira S, Uematsu S, Takeuchi O. Pathogen recognition and innate immunity. Cell. 2006; 124:783-801. doi: 10.1016/j. cell.2006.02.015.

5. Chen X, Zhao F, Zhang H, Zhu Y, Wu K, Tan G. Significance of TLR4/MyD88 expression in breast cancer. Int J Clin Exp Pathol. 2015; 8:7034-9.

6. Zaki MA, Wada N, Ikeda J, Shibayama H, Hashimoto K, Yamagami T, Tatsumi Y, Tsukaguchi M, Take H, Tsudo M, Morii E, Aozasa K. Prognostic implication of types of tumor-associated macrophages in Hodgkin lymphoma. Virchows Arch. 2011; 459:361-6. doi: 10.1007/s00428011-1140-8

7. Barros MH, Hassan R, Niedobitek G. Tumor-associated macrophages in pediatric classical Hodgkin lymphoma: association with Epstein-Barr virus, lymphocyte subsets, and prognostic impact. Clinic cancer Res. 2012; 18:3762-71. doi: 10.1158/1078-0432.CCR-12-0129.

8. Panico L, Ronconi F, Lepore M, Tenneriello V, Cantore N, Dell'Angelo AC, Ferbo U, Ferrara F. Prognostic role of tumor-associated macrophages and angiogenesis in classical Hodgkin lymphoma. Leukemia lymphoma. 2013; 54: 2418-25. doi: 10.3109/10428194.2013.778405.
9. Taskinen M, Karjalainen-Lindsberg ML, Nyman $\mathrm{H}$, Eerola LM, Leppa S. A high tumor-associated macrophage content predicts favorable outcome in follicular lymphoma patients treated with rituximab and cyclophosphamidedoxorubicin-vincristine-prednisone. Clinic Cancer Res. 2007; 13:5784-9. doi: 10.1158/1078-0432.CCR-07-0778.

10. Rajput S, Volk-Draper LD, Ran S. TLR4 is a novel determinant of the response to paclitaxel in breast cancer. Mol Cancer Ther. 2013; 12:1676-87. doi: 10.1158/15357163.MCT-12-1019.

11. Zhang $\mathrm{Y}$, Wang $\mathrm{Y}$, Yuan J, Qin W, Liu F, Wang F, Zhang G, Yang X. Toll-like receptor 4 ligation confers chemoresistance to docetaxel on PC-3 human prostate cancer cells. Cell Biol Toxicol. 2012; 28:269-77. doi: 10.1007/s10565-012-9221-2.

12. Apetoh L, Ghiringhelli F, Tesniere A, Obeid M, Ortiz C, Criollo A, Mignot G, Maiuri MC, Ullrich E, Saulnier P, Yang H, Amigorena S, Ryffel B, et al. Toll-like receptor 4-dependent contribution of the immune system to anticancer chemotherapy and radiotherapy. Nat Med. 2007; 13:1050-9. doi: 10.1038/nm1622.

13. Huang B, Zhao J, Li H, He KL, Chen Y, Chen SH, Mayer L, Unkeless JC, Xiong H. Toll-like receptors on tumor cells facilitate evasion of immune surveillance. Cancer Res. 2005; 65:5009-14. doi: 10.1158/0008-5472.CAN-05-0784.

14. Lissbrant IF, Stattin P, Wikstrom P, Damber JE, Egevad L, Bergh A. Tumor associated macrophages in human prostate cancer: relation to clinicopathological variables and survival. Int J Oncol. 2000; 17:445-51.

15. Nishie A, Ono M, Shono T, Fukushi J, Otsubo M, Onoue H, Ito Y, Inamura T, Ikezaki K, Fukui M, Iwaki T, Kuwano M. Macrophage infiltration and heme oxygenase-1 expression correlate with angiogenesis in human gliomas. Clin Cancer Res. 1999; 5:1107-13.

16. Koukourakis MI, Giatromanolaki A, Kakolyris S, O'Byrne KJ, Apostolikas N, Skarlatos J, Gatter KC, Harris AL. Different patterns of stromal and cancer cell thymidine phosphorylase reactivity in non-small-cell lung cancer: impact on tumour neoangiogenesis and survival. Br J Cancer. 1998; 77:1696-703.

17. Yusuf N, Nasti TH, Long JA, Naseemuddin M, Lucas AP, Xu $\mathrm{H}$, Elmets CA. Protective role of Toll-like receptor 4 during the initiation stage of cutaneous chemical carcinogenesis. Cancer Res. 2008; 68:615-22. doi: 10.1158/0008-5472.CAN-07-5219.

18. Yusuf N, Nasti TH, Meleth S, Elmets CA. Resveratrol enhances cell-mediated immune response to DMBA through TLR4 and prevents DMBA induced cutaneous carcinogenesis. Mol Carcinog. 2009; 48:713-23. doi: 10.1002/mc.20517.

19. Lee SJ, Shin SJ, Lee MH, Lee MG, Kang TH, Park WS, Soh BY, Park JH, Shin YK, Kim HW, Yun CH, Jung ID, Park YM. A potential protein adjuvant derived from Mycobacterium tuberculosis Rv0652 enhances dendritic cellsbased tumor immunotherapy. PloS One. 2014; 9:e104351. doi: 10.1371/journal.pone.0104351. 
20. Tesar BM, Jiang D, Liang J, Palmer SM, Noble PW, Goldstein DR. The role of hyaluronan degradation products as innate alloimmune agonists. Am J Transplant. 2006; 6: 2622-35. doi: 10.1111/j.1600-6143.2006.01537.x.

21. Kim JY, Kim YJ, Kim JS, Ryu HS, Lee HK, Kang JS, Kim HM, Hong JT, Kim Y, Han SB. Adjuvant effect of a natural TLR4 ligand on dendritic cell-based cancer immunotherapy. Cancer Lett. 2011; 313:226-34. doi: 10.1016/j. canlet.2011.09.009.

22. Kim JY, Yoon YD, Ahn JM, Kang JS, Park SK, Lee K, Song KB, Kim HM, Han SB. Angelan isolated from Angelica gigas Nakai induces dendritic cell maturation through toll-like receptor 4. Int Immunopharmacol. 2007; 7:78-87. doi: 10.1016/j.intimp.2006.08.017.

23. Yang S, Yang TS, Wang F, Su SB. High-mobility group box-1-Toll-Like receptor 4 axis mediates the recruitment of endothelial progenitor cells in alkali-induced corneal neovascularization. Int Immunopharmacol. 2015; 28:450-8. doi: 10.1016/j.intimp.2015.07.013

24. Chavakis E, Hain A, Vinci M, Carmona G, Bianchi ME, Vajkoczy P, Zeiher AM, Chavakis T, Dimmeler S. Highmobility group box 1 activates integrin-dependent homing of endothelial progenitor cells. Circ Res. 2007; 100:204-12. doi: 10.1161/01.RES.0000257774.55970.f4.

25. Qu X, Cinar MU, Fan H, Proll M, Tesfaye D, Tholen E, Looft C, Holker M, Schellander K, Uddin MJ. Comparison of the innate immune responses of porcine monocytederived dendritic cells and splenic dendritic cells stimulated with LPS. Innate Immun. 2015; 21:242-54. doi: $10.1177 / 1753425914526266$.

26. Davis MB, Vasquez-Dunddel D, Fu J, Albesiano E, Pardoll D, Kim YJ. Intratumoral administration of TLR4 agonist absorbed into a cellular vector improves antitumor responses. Clin Cancer Res. 2011; 17:3984-92. doi: 10.1158/1078-0432.CCR-10-3262.

27. Kang TH, Kim YS, Kim S, Yang B, Lee JJ, Lee HJ, Lee J, Jung ID, Han HD, Lee SH, Koh SS, Wu TC, Park YM. Pancreatic adenocarcinoma upregulated factor serves as adjuvant by activating dendritic cells through stimulation of TLR4. Oncotarget. 2015; 6:27751-62. doi: 10.18632/ oncotarget. 4859 .

28. Lin CC, Pan IH, Li YR, Pan YG, Lin MK, Lu YH, Wu HC, Chu CL. The adjuvant effects of high-molecule-weight polysaccharides purified from Antrodia cinnamomea on dendritic cell function and DNA vaccines. PloS One. 2015; 10:e0116191. doi: 10.1371/journal.pone.0116191.

29. Yang D, Postnikov YV, Li Y, Tewary P, de la Rosa G, Wei F, Klinman D, Gioannini T, Weiss JP, Furusawa T, Bustin M, Oppenheim JJ. High-mobility group nucleosomebinding protein 1 acts as an alarmin and is critical for lipopolysaccharide-induced immune responses. J Exp Med. 2012; 209:157-71. doi: 10.1084/jem.20101354.

30. Zhong H, Gutkin DW, Han B, Ma Y, Keskinov AA, Shurin MR, Shurin GV. Origin and pharmacological modulation of tumor-associated regulatory dendritic cells. Int J Cancer. 2014; 134:2633-45. doi: 10.1002/ijc.28590.

31. Fang H, Ang B, Xu X, Huang X, Wu Y, Sun Y, Wang W, Li N, Cao X, Wan T. TLR4 is essential for dendritic cell activation and anti-tumor T-cell response enhancement by DAMPs released from chemically stressed cancer cells. Cell Mol Immunol. 2014; 11:150-9. doi: 10.1038/cmi.2013.59.

32. Chai L, Wu S, Liu G, Wang Z, Tian W, Ma Y. OCILRP2 signaling synergizes with LPS to induce the maturation and differentiation of murine dendritic cells. B Biochem Biophys Res Commun. 2014; 446:836-42. doi: 10.1016/j. bbrc.2014.02.145.

33. Kolanowski ST, Dieker MC, Lissenberg-Thunnissen SN, van Schijndel GM, van Ham SM, ten Brinke A. TLR4-mediated pro-inflammatory dendritic cell differentiation in humans requires the combined action of MyD88 and TRIF. Innate Immun. 2014; 20:423-30. doi: $10.1177 / 1753425913498626$.

34. Grobner S, Lukowski R, Autenrieth IB, Ruth P. Lipopolysaccharide induces cell volume increase and migration of dendritic cells. Microbiol Immunol. 2014; 58:61-7. doi: 10.1111/1348-0421.12116.

35. Mantovani A, Sica A, Sozzani S, Allavena P, Vecchi A, Locati M. The chemokine system in diverse forms of macrophage activation and polarization. Trends Immunol. 2004; 25:677-86. doi: 10.1016/j.it.2004.09.015.

36. Robinson-Smith TM, Isaacsohn I, Mercer CA, Zhou M, Van Rooijen N, Husseinzadeh N, McFarland-Mancini MM, Drew AF. Macrophages mediate inflammation-enhanced metastasis of ovarian tumors in mice. Cancer Res. 2007; 67:5708-16. doi: 10.1158/0008-5472.CAN-06-4375.

37. Lee $\mathrm{CH}, \mathrm{Wu} \mathrm{CL}$, Shiau AL. Toll-like receptor 4 signaling promotes tumor growth. J Immunother. 2010; 33:73-82. doi: 10.1097/CJI.0b013e3181b7a0a4.

38. Karin M, Greten FR. NF-kappaB. Linking inflammation and immunity to cancer development and progression. Nat Rev Immunol. 2005; 5:749-59. doi: 10.1038/nri1703.

39. Giraudo E, Inoue M, Hanahan D. An amino-bisphosphonate targets MMP-9-expressing macrophages and angiogenesis to impair cervical carcinogenesis. J Clin Invest. 2004; 114:623-33. doi: 10.1172/JCI22087.

40. Hakim F, Wang Y, Zhang SX, Zheng J, Yolcu ES, Carreras A, Khalyfa A, Shirwan H, Almendros I, Gozal D. Fragmented sleep accelerates tumor growth and progression through recruitment of tumor-associated macrophages and TLR4 signaling. Cancer Res. 2014; 74:1329-37. doi: 10.1158/0008-5472.CAN-13-3014.

41. Wang X, Li X, Zhang X, Zang L, Yang H, Zhao W, Zhao H, Li Q, Xia B, Yu Y, Wang Y, Zhao Z, Zhang Y. Toll-like receptor 4-induced inflammatory responses contribute to the tumor-associated macrophages formation and infiltration in patients with diffuse large B-cell lymphoma. Ann Diagn Pathol. 2015; 19:232-8. doi: 10.1016/j. anndiagpath.2015.04.008. 
42. Orr MT, Fox CB, Baldwin SL, Sivananthan SJ, Lucas E, Lin S, Phan T, Moon JJ, Vedvick TS, Reed SG, Coler RN. Adjuvant formulation structure and composition are critical for the development of an effective vaccine against tuberculosis. J Control Release. 2013; 172:190-200. doi: 10.1016/j.jconrel.2013.07.030.

43. Coler RN, Bertholet S, Moutaftsi M, Guderian JA, Windish HP, Baldwin SL, Laughlin EM, Duthie MS, Fox CB, Carter D, Friede M, Vedvick TS, Reed SG. Development and characterization of synthetic glucopyranosyl lipid adjuvant system as a vaccine adjuvant. PloS One. 2011; 6:e16333. doi: 10.1371/journal. pone. 0016333 .

44. Coler RN, Hudson T, Hughes S, Huang PW, Beebe EA, Orr MT. Vaccination Produces CD4 T Cells with a Novel CD154-CD40-Dependent Cytolytic Mechanism. J Immunol. 2015; 195:3190-7. doi: 10.4049/jimmunol.1501118.

45. Graham CM, Christensen JR, Thomas DB. Differential induction of CD94 and NKG2 in CD4 helper T cells. A consequence of influenza virus infection and interferongamma? Immunology. 2007; 121:238-47. doi: 10.1111/j.1365-2567.2007.02563.x.

46. Saez-Borderias A, Guma M, Angulo A, Bellosillo B, Pende D, Lopez-Botet M. Expression and function of NKG2D in CD4+ T cells specific for human cytomegalovirus. Eur J Immunol. 2006; 36:3198-206. doi: 10.1002/eji.200636682.

47. Soghoian DZ, Jessen H, Flanders M, Sierra-Davidson K, Cutler S, Pertel T, Ranasinghe S, Lindqvist M, Davis I, Lane K, Rychert J, Rosenberg ES, Piechocka-Trocha A, et al. HIV-specific cytolytic CD4 T cell responses during acute HIV infection predict disease outcome. Sci Transl Med. 2012; 4:123ra25. doi: 10.1126/scitranslmed.3003165.

48. Bijker EM, Teirlinck AC, Schats R, van Gemert GJ, van de Vegte-Bolmer M, van Lieshout L, IntHout J, Hermsen CC, Scholzen A, Visser LG, Sauerwein RW. Cytotoxic markers associate with protection against malaria in human volunteers immunized with Plasmodium falciparum sporozoites. J Infect Dis. 2014; 210:1605-15. doi: 10.1093/ infdis/jiu293.

49. Takeuchi A, Saito T. CD4 CTL, a Cytotoxic Subset of CD4+ T Cells, Their Differentiation and Function. Front Immunol. 2017; 8:194. doi: 10.3389/fimmu.2017.00194.

50. Wild CA, Bergmann C, Fritz G, Schuler P, Hoffmann TK, Lotfi R, Westendorf A, Brandau S, Lang S. HMGB1 conveys immunosuppressive characteristics on regulatory and conventional T cells. Int Immunol. 2012; 24:485-94. doi: 10.1093/intimm/dxs051.

51. Chan SL, Mo F, Wong SC, Hui EP, Loong HH, Mok T, Chan AT, Yeo W. The significance of serum interleukin-10 on the outcome of unresectable hepatocellular carcinoma (HCC). J Clin Oncol. 2011; 29:205.

52. Fujieda S, Lee K, Sunaga H, Tsuzuki H, Ikawa H, Fan GK, Imanaka M, Takenaka H, Saito H. Staining of interleukin-10 predicts clinical outcome in patients with nasopharyngeal carcinoma. Cancer.1999; 85:1439-45.
53. Liu Z, Falo LD Jr, You Z. Knockdown of HMGB1 in tumor cells attenuates their ability to induce regulatory $T$ cells and uncovers naturally acquired CD8 T cell-dependent antitumor immunity. J Immunol. 2011; 187:118-25. doi: 10.4049/jimmunol.1003378.

54. Park IA, Heo SH, Song IH, Kim YA, Park HS, Bang WS, Park SY, Jo JH, Lee HJ, Gong G. Endoplasmic reticulum stress induces secretion of high-mobility group proteins and is associated with tumor-infiltrating lymphocytes in triplenegative breast cancer. Oncotarget. 2016; 7:59957-59964. doi: 10.18632/oncotarget.11010.

55. Youn JI, Nagaraj S, Collazo M, Gabrilovich DI. Subsets of myeloid-derived suppressor cells in tumor-bearing mice. J Immunol. 2008; 181:5791-802.

56. Hestdal K, Ruscetti FW, Ihle JN, Jacobsen SE, Dubois CM, Kopp WC, Longo DL, Keller JR. Characterization and regulation of RB6-8C5 antigen expression on murine bone marrow cells. J Immunol. 1991; 147:22-8.

57. Chang SH, Mirabolfathinejad SG, Katta H, Cumpian AM, Gong L, Caetano MS, Moghaddam SJ, Dong C. T helper 17 cells play a critical pathogenic role in lung cancer. Proc Natl Acad Sci USA. 2014; 111:5664-9. doi: 10.1073/ pnas. 1319051111.

58. Bunt SK, Clements VK, Hanson EM, Sinha P, OstrandRosenberg S. Inflammation enhances myeloid-derived suppressor cell cross-talk by signaling through Tolllike receptor 4. J Leukoc Biol . 2009; 85:996-1004. doi: 10.1189/jlb.0708446.

59. Gabrilovich DI, Nagaraj S. Myeloid-derived suppressor cells as regulators of the immune system. Nat Rev Immunol. 2009; 9:162-74. doi: 10.1038/nri2506.

60. Srivastava MK, Zhu L, Harris-White M, Kar UK, Huang M, Johnson MF, Lee JM, Elashoff D, Strieter R, Dubinett S, Sharma S. Myeloid suppressor cell depletion augments antitumor activity in lung cancer. PloS One. 2012; 7:e40677. doi: 10.1371/journal.pone.0040677.

61. Teixeira D, Almeida JS, Visniauskas B, Gomes GN, Hirata AE, Bueno V. Myeloid-derived suppressor cells and associated events in urethane-induced lung cancer. Clinics. 2013; 68:858-64. doi: 10.6061/clinics/201322.

62. Chen J, Sun B, Zhao X, Liang D, Liu J, Huang Y, Lei W, Chen M, Sun W. Monophosphoryl lipid A induces bone marrow precursor cells to differentiate into myeloidderived suppressor cells. Mol Med Rep. 2013; 8:1074-8. doi: 10.3892/mmr.2013.1653.

63. Talmadge JE. Pathways mediating the expansion and immunosuppressive activity of myeloid-derived suppressor cells and their relevance to cancer therapy. Clin Cancer Res. 2007; 13:5243-8. doi: 10.1158/1078-0432.CCR-07-0182.

64. Liu YY, Sun LC, Wei JJ, Li D, Yuan Y, Yan B, Liang ZH, Zhu HF, Xu Y, Li B, Song CW, Liao SJ, Lei Z, et al. Tumor cell-released TLR4 ligands stimulate Gr-1+CD11b+F4/80+ cells to induce apoptosis of activated T cells. J Immunol. 2010; 185:2773-82. doi: 10.4049/jimmunol.1000772. 
65. Youn HS, Lee JY, Fitzgerald KA, Young HA, Akira S, Hwang DH. Specific inhibition of MyD88-independent signaling pathways of TLR3 and TLR4 by resveratrol: molecular targets are TBK1 and RIP1 in TRIF complex. J Immunol. 2005; 175:3339-46.

66. Song J, Lee J, Kim J, Jo S, Kim YJ, Baek JE, Kwon ES, Lee KP, Yang S, Kwon KS, Kim DU, Kang TH, Park YY, et al. Pancreatic adenocarcinoma up-regulated factor (PAUF) enhances the accumulation and functional activity of myeloid-derived suppressor cells (MDSCs) in pancreatic cancer. Oncotarget. 2016; 7:51840-53. doi: 10.18632/ oncotarget. 10123.

67. De Wilde V, Van Rompaey N, Hill M, Lebrun JF, Lemaitre P, Lhomme F, Kubjak C, Vokaer B, Oldenhove G, Charbonnier LM, Cuturi MC, Goldman M, Le Moine A. Endotoxin-induced myeloid-derived suppressor cells inhibit alloimmune responses via heme oxygenase-1. Am J Transplant. 2009; 9:2034-47. doi: 10.1111/j.16006143.2009.02757.x.

68. Cervera R, Khamashta MA, Shoenfeld Y, Camps MT, Jacobsen S, Kiss E, Zeher MM, Tincani A, KontopoulouGriva I, Galeazzi M, Bellisai F, Meroni PL, Derksen RH, et al. Morbidity and mortality in the antiphospholipid syndrome during a 5-year period: a multicentre prospective study of 1000 patients. Ann Rheum Dis. 2009; 68:1428-32. doi: 10.1136/ard.2008.093179.

69. Lin Q, Yang XP, Fang D, Ren X, Zhou H, Fang J, Liu X, Zhou S, Wen F, Yao X, Wang JM, Su SB. High-mobility group box-1 mediates toll-like receptor 4-dependent angiogenesis. Arterioscler Thromb Vasc Biol. 2011; 31:1024-32. doi: 10.1161/ATVBAHA.111.224048.

70. Park JS, Svetkauskaite D, He Q, Kim JY, Strassheim D, Ishizaka A, Abraham E. Involvement of toll-like receptors 2 and 4 in cellular activation by high mobility group box 1 protein. J Biol Chem. 2004; 279:7370-7. doi: 10.1074/jbc. M306793200.

71. Zhu L, Ren L, Chen Y, Fang J, Ge Z, Li X. Redox status of high-mobility group box 1 performs a dual role in angiogenesis of colorectal carcinoma. J Cell Mol Med. 2015; 19:2128-35. doi: 10.1111/jcmm.12577.

72. Riddell JR, Wang XY, Minderman H, Gollnick SO. Peroxiredoxin 1 stimulates secretion of proinflammatory cytokines by binding to TLR4. J Immunol. 2010; 184: 1022-30. doi: 10.4049/jimmunol.0901945.

73. Riddell JR, Bshara W, Moser MT, Spernyak JA, Foster BA, Gollnick SO. Peroxiredoxin 1 controls prostate cancer growth through Toll-like receptor 4-dependent regulation of tumor vasculature. Cancer Res. 2011; 71:1637-46. doi: 10.1158/0008-5472.CAN-10-3674.

74. Riddell JR, Maier P, Sass SN, Moser MT, Foster BA, Gollnick SO. Peroxiredoxin 1 stimulates endothelial cell expression of VEGF via TLR4 dependent activation of HIF1alpha. PloS One. 2012; 7:e50394. doi: 10.1371/journal. pone. 0050394 .
75. Hu L, Zang MD, Wang HX, Li JF, Su LP, Yan M, Li C, Yang QM, Liu BY, Zhu ZG. Biglycan stimulates VEGF expression in endothelial cells by activating the TLR signaling pathway. Mol Oncol. 2016; 10:1473-84. doi: 10.1016/j.molonc.2016.08.002.

76. Karnoub AE, Dash AB, Vo AP, Sullivan A, Brooks MW, Bell GW, Richardson AL, Polyak K, Tubo R, Weinberg RA. Mesenchymal stem cells within tumour stroma promote breast cancer metastasis. Nature. 2007; 449:557-63. doi: 10.1038 /nature06188.

77. Kuhn NZ, Tuan RS. Regulation of stemness and stem cell niche of mesenchymal stem cells: implications in tumorigenesis and metastasis. J Cell Physiol. 2010; 222:268-77. doi: 10.1002/jcp.21940.

78. Shi L, Wang JS, Liu XM, Hu XY, Fang Q. Upregulated functional expression of Toll like receptor 4 in mesenchymal stem cells induced by lipopolysaccharide. Chin Med J (Engl). 2007; 120:1685-8.

79. Liotta F, Angeli R, Cosmi L, Fili L, Manuelli C, Frosali F, Mazzinghi B, Maggi L, Pasini A, Lisi V, Santarlasci V, Consoloni L, Angelotti ML, et al. Toll-like receptors 3 and 4 are expressed by human bone marrow-derived mesenchymal stem cells and can inhibit their T-cell modulatory activity by impairing Notch signaling. Stem Cells. 2008; 26:279-89. doi: 10.1634/stemcells.2007-0454.

80. Gazdic M, Volarevic V, Arsenijevic N, Stojkovic M. Mesenchymal stem cells: a friend or foe in immunemediated diseases. Stem Cell Rev. 2015; 11:280-7. doi: 10.1007/s12015-014-9583-3.

81. Yan H, Wu M, Yuan Y, Wang ZZ, Jiang H, Chen T. Priming of Toll-like receptor 4 pathway in mesenchymal stem cells increases expression of B cell activating factor. Biochem Biophys Res Commun. 2014; 448:212-7. doi: 10.1016/j. bbrc.2014.04.097.

82. Han D, Wu C, Xiong Q, Zhou L, Tian Y. Anti-inflammatory Mechanism of Bone Marrow Mesenchymal Stem Cell Transplantation in Rat Model of Spinal Cord Injury. Cell Biochem Biophys. 2015; 71:1341-7. doi: 10.1007/s12013014-0354-1.

83. Lu Y, Liu J, Liu Y, Qin Y, Luo Q, Wang Q, Duan H. TLR4 plays a crucial role in MSC-induced inhibition of NK cell function. Biochem Biophys Res Commun. 2015; 464: 541-7. doi: 10.1016/j.bbrc.2015.07.002.

84. Goldstein RH, Reagan MR, Anderson K, Kaplan DL, Rosenblatt M. Human bone marrow-derived MSCs can home to orthotopic breast cancer tumors and promote bone metastasis. Cancer Res. 2010; 70:10044-50. doi: 10.1158/0008-5472.CAN-10-1254.

85. Thuringer D, Hammann A, Benikhlef N, Fourmaux E, Bouchot A, Wettstein G, Solary E, Garrido C. Transactivation of the epidermal growth factor receptor by heat shock protein 90 via Toll-like receptor 4 contributes to the migration of glioblastoma cells. J Biol Chem. 2011; 286:3418-28. doi: 10.1074/jbc.M110.154823. 
86. Gong W, Wang ZY, Chen GX, Liu YQ, Gu XY, Liu WW. Invasion potential of $\mathrm{H} 22$ hepatocarcinoma cells is increased by HMGB1-induced tumor NF-kappaB signaling via initiation of HSP70. Oncol Rep. 2013; 30:1249-56. doi: 10.3892/or.2013.2595.

87. Wang C, Fei G, Liu Z, Li Q, Xu Z, Ren T. HMGB1 was a pivotal synergistic effecor for $\mathrm{CpG}$ oligonucleotide to enhance the progression of human lung cancer cells. Cancer Biol Ther. 2012; 13:727-36. doi: 10.4161/cbt.20555.

88. Yang H, Wang B, Wang T, Xu L, He C, Wen H, Yan J, Su H, Zhu X. Toll-like receptor 4 prompts human breast cancer cells invasiveness via lipopolysaccharide stimulation and is overexpressed in patients with lymph node metastasis. PloS One. 2014; 9:e109980. doi: 10.1371/journal.pone.0109980.

89. Basu S, Binder RJ, Suto R, Anderson KM, Srivastava PK. Necrotic but not apoptotic cell death releases heat shock proteins, which deliver a partial maturation signal to dendritic cells and activate the NF-kappa B pathway. Int Immunol. 2000; 12:1539-46.

90. Lee SG, Su ZZ, Emdad L, Sarkar D, Fisher PB. Astrocyte elevated gene-1 (AEG-1) is a target gene of oncogenic Haras requiring phosphatidylinositol 3-kinase and c-Myc. Proc Natl Acad Sci USA. 2006; 103:17390-5. doi: 10.1073/ pnas.0608386103.

91. Pikarsky E, Porat RM, Stein I, Abramovitch R, Amit S, Kasem S, Gutkovich-Pyest E, Urieli-Shoval S, Galun E, Ben-Neriah Y. NF-kappaB functions as a tumour promoter in inflammation-associated cancer. Nature. 2004; 431:461-6. doi: 10.1038/nature02924.

92. Zhao Y, Kong X, Li X, Yan S, Yuan C, Hu W, Yang Q. Metadherin mediates lipopolysaccharide-induced migration and invasion of breast cancer cells. PloS One. 2011; 6:e29363. doi: 10.1371/journal.pone.0029363.

93. Zhou YH, Liao SJ, Li D, Luo J, Wei JJ, Yan B, Sun R, Shu Y, Wang Q, Zhang GM, Feng ZH. TLR4 ligand/H(2)O(2) enhances TGF-betal signaling to induce metastatic potential of non-invasive breast cancer cells by activating non-Smad pathways. PloS One. 2013; 8:e65906. doi: 10.1371/journal. pone.0065906.

94. Ghochikyan A, Pichugin A, Bagaev A, Davtyan A, Hovakimyan A, Tukhvatulin A, Davtyan H, Shcheblyakov D, Logunov D, Chulkina M, Agadjanyan MG, Ataullakhanov RI. Targeting TLR-4 with a novel pharmaceutical grade plant derived agonist, Immunomax(R), as a therapeutic strategy for metastatic breast cancer. J Transl Med. 2014; 12:322. doi: 10.1186/s12967-014-0322-y.
95. Ma FJ, Liu ZB, Hu X, Ling H, Li S, Wu J, Shao ZM. Prognostic value of myeloid differentiation primary response 88 and Toll-like receptor 4 in breast cancer patients. PloS One. 2014; 9:e111639. doi: 10.1371/journal.pone.0111639.

96. Mallick P, Basu S, Moorthy B, Ghose R. Role of Toll-like receptor 4 in drug-drug interaction between paclitaxel and irinotecan in vitro. Toxicol In Vitro. 2017; 41:75-82. doi: 10.1016/j.tiv.2017.02.019.

97. Woods DC, White YA, Dau C, Johnson AL. TLR4 activates NF-kappaB in human ovarian granulosa tumor cells. Biochem Biophys Res Commun. 2011; 409:675-80. doi: 10.1016/j.bbrc.2011.05.063.

98. Yang H, Zhou H, Feng P, Zhou X, Wen H, Xie X, Shen H, Zhu X. Reduced expression of Toll-like receptor 4 inhibits human breast cancer cells proliferation and inflammatory cytokines secretion. J Exp Clin Cancer Res. 2010; 29:92. doi: 10.1186/1756-9966-29-92.

99. Fu HY, Li C, Yang W, Gai XD, Jia T, Lei YM, Li Y. FOXP3 and TLR4 protein expression are correlated in non-small cell lung cancer: implications for tumor progression and escape. Acta Histochem. 2013; 115:151-7. doi: 10.1016/j. acthis.2012.06.002.

100. Lan F, Yue X, Ren G, Wang Y, Xia T. Serum toll-like receptors are potential biomarkers of radiation pneumonia in locally advanced NSCLC. Int J Clin Exp Pathol. 2014; 7:8087-95.

101. Sussman DA, Santaolalla R, Bejarano PA, GarciaBuitrago MT, Perez MT, Abreu MT, Clarke J. In silico and Ex vivo approaches identify a role for toll-like receptor 4 in colorectal cancer. J Exp Clin Cancer Res. 2014;33:45. doi: 10.1186/1756-9966-33-45.

102. Wang E, Feng Y, Zhang M, Zou L, Li Y, Buys ES, Huang P, Brouckaert $\mathrm{P}$, Chao W. Toll-like receptor 4 signaling confers cardiac protection against ischemic injury via inducible nitric oxide synthase- and soluble guanylate cyclasedependent mechanisms. Anesthesiology. 2011; 114:603-13. doi: 10.1097/ALN.0b013e31820a4d5b.

103. Liu WT, Jing YY, Yu GF, Han ZP, Yu DD, Fan QM, Ye F, Li R, Gao L, Zhao QD, Wu MC, Wei LX. Toll like receptor 4 facilitates invasion and migration as a cancer stem cell marker in hepatocellular carcinoma. Cancer Lett. 2015; 358:136-43. doi: 10.1016/j.canlet.2014.12.019.

104. Wei F, Yang F, Li J, Zheng Y, Yu W, Yang L, Ren X. Soluble Toll-like receptor 4 is a potential serum biomarker in nonsmall cell lung cancer. Oncotarget. 2016; 7:40106-14. doi: 10.18632/oncotarget.9496. 